\title{
Effect of different irrigation period and potassium humate on some soil properties and carrot productivity under saline soil conditions
}

\author{
AbdEIghany S.H., Shereen A.H. Saad, A. A. Arafat and Shaban Kh
}

Soils, Water and Environ. Res. Inst., Agric. Res. Center, Giza, Egypt. Received: 22 Oct. 2019 / Accepted 10 Dec. 2019 / Publication date: 15 Dec. 2019

\begin{abstract}
A field experiment was conducted in the farm of Sahl El-Hussinia Agricultural Research Station, El-Sharkia Governorate, Egypt during 2016/2017 and 2017/2018 winter seasons. The impact of potassium humate at different rates $(0,2,4$ and $6 \mathrm{~g} / \mathrm{L})$ and irrigation water at different periods 10,15 , and 20 days applied during growth period was studied on some physical and chemical soil properties and Carrot (Daucus carota L.) productivity under saline soil conditions. The obtained results stated that soil $\mathrm{pH}$ changed to slightly or moderately alkaline conditions ranged between 8.27 and 8.05. Soil salinity $\left(\mathrm{ECdSm}^{-1}\right)$ values tended to decrease by increasing potassium humate applied and decreasing the irrigation period, the study showed that 10 days irrigation period gave the highest effects on soil salinity than other periods tested. Also, it emphasized that irrigation water periods and increasing of potassium humate applied significantly increased availability of some macro and micronutrients represented by N, P, K, Fe, Mn and $\mathrm{Zn}$ contents in soil after harvest of carrot. This increase led to increase these nutrients in leaves and roots of carrot plants beside weight of fresh roots and the total yield (ton/fed). The study implies application of potassium humate at $6 \mathrm{~g} / \mathrm{l}$ and 10 days irrigation period was the best treatment over the two seasons.
\end{abstract}

Keywords: irrigation period, Soil properties, Carrot productivity, saline soil, potassium humate

\section{Introduction}

The majority of salt-affected soils in Egypt are located in the North central part of the Nile Delta and on its Eastern and Western sides. About 900000 ha of cultivated irrigated areas suffer from salinity problems. For example, about $6 \%$ of North Delta soils, $20 \%$ of the South Delta and Middle Egyptian regions and $25 \%$ of the Upper Egypt region are salt-affected soils (FAO, 2003).

Scheduling the required irrigation water for each crop will help in minimizing loose of water during the growing seasons. Regulated deficit irrigation is water saving technology that is relatively inexpensive and easy to implement (Webber et al., 2007). El-Salam Canal is one of the national promising projects involves the reuse of agricultural drainage water, after reducing its salinity levels by mixing it with Nile water with Bahr Hadoos drains (1.095 milliard $\mathrm{m}^{3}$ drainage water) and El-Serw drain (1.245 milliard $\mathrm{m}^{3}$ drainage water), which are considered the main source of the drainage water, while the fresh Nile water is about 2.11 milliard $\mathrm{m}^{3}$ water Shaban (2005). Deficit irrigation (DI) index could be used to raise the ratio between crop yield and crop water consumption in different crops stages and to eliminate water stress (Geerts and Raes, 2009). On (Geerts and Raes, 2009). On the other hand, the scheduling irrigation, decrement in plant size due to decreasing in prolongation of cells and cell division moreover increment in leaf thickness and in general reduction in yield and yield components as available soil water depletion increased (Marzouk et al., 2016).

Potassium humate is considered as an organic fertilizer. It contains $5 \%$ nitrogen, $2.8 \%$ phosphorus, $10 \%$ potassium and some micronutrients including molybdenum, copper, zinc, cobalt and magnesium .Potassium humate increases product quality and plant tolerance to drought stress, salinity, heat, cold, disease and pests (Khordhidi et al. (2009). Humic acids improved soil structure, cation exchange capacity, nutrient retention and soil microbial activity. The impact of humic acids will therefore be comprehensively discussed under physical, chemical and biological soil properties, (Johan, 2008). Foliar application of humic substances is increasingly used in agricultural practice, the mechanism of possible growth promoting effect, usually attributed to hormone-like impact, activation of photosynthesis, accelerate cell division, increase the permeability of plant cell membranes and improved nutrient uptake, reduce the uptake of toxic elements and improve the plant response to salinity 
(Verlinden et al. 2009). In addition, the important of potassium $\mathrm{k}^{+}$represented in photosynthesis, increasing enzyme activity, improving synthesis of protein, carbohydrates and fats, translocation of photosynthetic, enabling their ability to resist, pests and diseases. Also, potassium has osmotic action for plant cells (Mehdi et al., 2007). El-Tohamy et al. (2011) found that the application of potassium rates was significantly improved carrot growth i.e. plant height, number of leaves and fresh and dry weight of leaves, yield (fresh and dry weight of roots) and (root length and diameter) compared to control plants.

Carrot (Daucus carota L.) is an important vegetable in Egypt. It covers a production area of 13,651 fed. in year 2010 that yielded 175,923 tons according to Ministry of Agriculture Statistics, and Abdel Naby et al. (2013). Carrots (Daucus carota L.), is the most important root vegetables in the Apiaceae family,which are cultivated worldwide. The storage root is widely utilized due to its richness in carotenoids, anthocyanins, dietary fiber, vitamins and other nutrients, Feng et al. (2019).

This study aims to determine the effects of applied potassium humate and irrigation periods on the some soil chemical properties and carrot production under saline conditions.

\section{Materials and Methods}

\section{Experiment location}

A field experiment was conducted in the farm of Sahl El-Hussinia Agricultural Research Station, El-Sharkia Governorate, Egypt during 2016/2017 and 2017/2018 winter seasons, the location lies between $32^{\circ} / 00$ to $32^{\circ} / 15, \mathrm{~N}$ latitude and $30^{\circ} / 50$ to $31^{\circ} / 15 \mathrm{E}$ longitude.

\section{Soil Sampling}

The soil samples for initial and after harvests were collected from a depth of $0-30 \mathrm{~cm}$ for all replication and analysis of physical and chemical properties were determined Page et al. (1982).

Table 1: Some physical and chemical properties of the soil used before Carrot planting.

\begin{tabular}{|c|c|c|c|c|c|c|c|c|}
\hline \multicolumn{2}{|c|}{ Sand (\%) } & $\begin{array}{l}\text { Silt } \\
(\%)\end{array}$ & $\begin{array}{l}\text { Clay } \\
(\%)\end{array}$ & \multicolumn{2}{|c|}{ Texture } & \multicolumn{2}{|c|}{$\begin{array}{l}\text { O.M } \\
(\%)\end{array}$} & $\begin{array}{c}\mathrm{CaCO}_{3} \\
(\%)\end{array}$ \\
\hline \multicolumn{2}{|c|}{22.18} & 35.74 & 42.08 & \multicolumn{2}{|c|}{ Clay } & \multicolumn{2}{|c|}{0.62} & 9.74 \\
\hline \multirow[t]{2}{*}{$\begin{array}{c}\mathrm{pH} \\
(1: 2.5)\end{array}$} & \multirow{2}{*}{$\begin{array}{c}E C \\
(d S / m) \text { in } \\
\text { soil past }\end{array}$} & \multicolumn{4}{|c|}{$\begin{array}{l}\text { Soluble Cations } \\
\quad\left(\text { meq l}^{l^{-1}}\right)\end{array}$} & \multicolumn{3}{|c|}{$\begin{array}{l}\text { Soluble Anions } \\
\quad\left(\text { meq }^{-1}\right)\end{array}$} \\
\hline & & $\mathrm{Ca}^{+2}$ & $\mathbf{M g}^{+2}$ & $\mathbf{N a}^{+}$ & $\mathbf{K}^{+}$ & $\mathrm{HCO}_{3}^{-}$ & $\mathrm{Cl}^{-}$ & $\mathrm{SO}^{-2}{ }_{4}$ \\
\hline 8.35 & 10.85 & 8.29 & 14.93 & 84.50 & 0.78 & 9.71 & 60.62 & 29.67 \\
\hline \multicolumn{3}{|c|}{$\begin{array}{l}\text { Available macronutrients } \\
\qquad(\mathrm{mg} / \mathrm{kg})\end{array}$} & \multicolumn{6}{|c|}{$\begin{array}{l}\text { Available micronutrients } \\
\qquad(\mathrm{mg} / \mathrm{kg})\end{array}$} \\
\hline $\mathbf{N}$ & $\mathbf{P}$ & K & & $\mathrm{Fe}$ & & Mn & & \\
\hline 37.85 & 4.35 & 188 & & 5.74 & & 2.64 & & \\
\hline
\end{tabular}

The experimental design was split plot arranged with six replicates. The rates of potassium humate were in the main plot and different periods of irrigation were in the sub plots.

To control soil salinity, irrigation water was applied immediately after sowing for 4 hours and then the excess water was surface drained in same day of sowing. The same process was repeated in the second day. Irrigation water was applied at interval periods of 10,15 and 20 days from planting. Irrigation water was controlled by the water meter fixed on the irrigation pipe. The quantity of irrigation water applied was $\left(2000,1500\right.$ and $\left.1000 \mathrm{~m}^{3} / \mathrm{fed} / \mathrm{season}\right)$ for the whole growth season which corresponding to 10,15 and 20 days of irrigation frequencies/season, respectively.

The mean values of chemical properties in irrigation water from El-Salam canal analysis are shown in Table (2).

The selected Varity of carrot seeds is New Kuroda (a Japanese variety), applied at rate $2.5 \mathrm{~kg}$ /fed. The seeds were sown on 5 November of $2016 / 2017$ and 2017/2018 seasons respectively, the hill 
spacing was $25 \mathrm{~cm}$ between plants. Seedling was thinned to one plant for each hill after 21 days from planting.

Table 2: Chemical analysis of irrigation water used during carrot planting (average of two years).

\begin{tabular}{|c|c|c|c|c|c|c|c|c|}
\hline \multirow[b]{2}{*}{ pH } & \multirow{2}{*}{$\begin{array}{c}\text { EC } \\
\left(\mathbf{d S}^{-1}\right)\end{array}$} & \multirow{2}{*}{\multicolumn{2}{|c|}{$\begin{array}{c}\mathbf{N} \\
\left(\mathrm{mgkg}^{-1}\right)\end{array}$}} & $\mathbf{P}$ & K & $\mathbf{F e}$ & Mn & Zn \\
\hline & & & & \multicolumn{5}{|c|}{$\left(\mathrm{mgkg}^{-1}\right)$} \\
\hline 7.89 & 1.20 & 15.84 & 7.30 & 5.95 & 8.31 & 1.77 & 1.04 & 0.55 \\
\hline
\end{tabular}

Super phosphate $\left(15.5 \mathrm{P}_{2} \mathrm{O}_{5} \%\right)$ was applied at a rate of $31 \mathrm{~kg} \mathrm{P}_{2} \mathrm{O}_{5} /$ fed during tillage of soil before planting. Urea $(46 \% \mathrm{~N})$ was applied at rate $100 \mathrm{~kg} \mathrm{~N}$ at three periods 25,45 and 65 days from planting. Potassium humate was foliar application on soil and plant at a rate $0,2,4,6 \mathrm{~g} / \mathrm{L}(800,1600$ and 3600 $\mathrm{ml} / 400 \mathrm{~L}$ water/fed) on two periods 21 and 55 days after planting.

At harvesting stage; 160 days after sowing, total roots yield (ton/fed) was estimated. Plants sample from ten plants of each plot was taken at random and the following measurements were recorded: plant height $(\mathrm{cm})$, Root length $(\mathrm{cm})$, root diameter $(\mathrm{cm})$, Weight of Fresh roots $(\mathrm{g})$ and Weight of fresh root (ton/fed).

\section{Plant analysis:}

A sample of plant (root and leaves) ( $0.5 \mathrm{~g}$ dry matter) were digested by concentrated digestion mixture of $\mathrm{H}_{2} \mathrm{SO}_{4} / \mathrm{HCLO}_{4}$ acids according to Sommers and Nelson (1972). Nitrogen was determined by micro Keldahl, according to Jackson (1973). Phosphorus was determined Spectrophotometrcally using ammonium molybdate/ stannus chloride method according to Chapman and Pratt (1978). Potassium was determined by a flame photometer, according to Page et al. (1982). Fe, Mn, and Zn were determined by using Atomic Absorption (model GBC 932).

\section{Climatic condition:}

The meteorological data including temperature $\left({ }^{\circ} \mathrm{C}\right)$ and rainfall $(\mathrm{mm} / \mathrm{month})$ during the two years of study had been obtained from the agro meteorological Unit at SWERI, ARC and their monthly mean values and are presented in Table (3).

Table 3: Temperature and rainfall during the two growing seasons.

\begin{tabular}{|c|c|c|c|c|c|c|}
\hline \multirow{3}{*}{ Month } & \multicolumn{4}{|c|}{ Temperature $\left(\mathrm{C}^{0}\right)$} & \multicolumn{2}{|c|}{ Rain full (mm) } \\
\hline & \multicolumn{2}{|c|}{$2016 / 2017$} & \multicolumn{2}{|c|}{$2017 / 2018$} & \multirow{2}{*}{ 2016/2017 } & \multirow{2}{*}{$2017 / 2018$} \\
\hline & Max & Min & Max & Min & & \\
\hline December & 30 & 18 & 32 & 17 & 65 & 73 \\
\hline January & 18 & 10 & 17 & 12 & 80 & 85 \\
\hline February & 15 & 9 & 14 & 11 & 100 & 95 \\
\hline March & 25 & 14 & 29 & 16 & 35 & 50 \\
\hline April & 34 & 20 & 33 & 19 & 20 & 35 \\
\hline
\end{tabular}

\section{Statistical analysis:}

All measurements were carried out in triplicate. The statistical significance of the treatment effects calculated with LSD procedure at $\mathrm{p}=0.05$ by using SPSS software programs.

Relative percent compared to control=

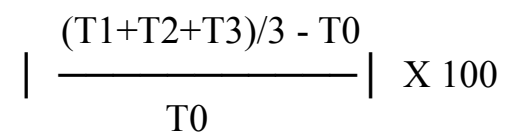

Where;

$\mathrm{T}_{0}$ : parameter value without treatment (control)

$\mathrm{T}_{1}$ : parameter value at $2 \mathrm{~g} / 1$ of potassium humate treatment

$\mathrm{T}_{2}$ : parameter value at $4 \mathrm{~g} / \mathrm{l}$ of potassium humate treatment

$\mathrm{T}_{3}$ : parameter value at $6 \mathrm{~g} / 1$ of potassium humate treatment 


\section{Results and Discussion}

\section{1- Soil pH}

Data in Table (4) show that soil $\mathrm{pH}$ tends to decrease slightly after the leaching process as affected by irrigation water periods and potassium humate application. The soil $\mathrm{pH}$ ranged to slightly and moderately alkaline conditions, where the soil $\mathrm{pH}$ value is always around 8.27 to 8.05 . However, there was a clear effect for the application of high rate of potassium humate and water quanities on the soil $\mathrm{pH}$ decreasing. The slight decrease of soil $\mathrm{pH}$ values may reflect the activity of microorganisms in decomposing organic matter and releasing organic acids. Also, parallel same trend was noticed for carrot at harvesting in cases of irrigation at 10 and 15 days combined with high rate of potassium humate. The relative decreases of mean values in soil $\mathrm{pH}$ were $1.46 ; 1.09$ and $1.09 \%$ for irrigated at 10,15 and 20 days periods respectively combined with potassium humate compared to the $\mathrm{pH}$ values of irrigated soil without potassium humate treatment. The decline of soil $\mathrm{pH}$ from adding humic substances and gypsum to the alkali soils has been reported by Li et al. (2012). This can be attribute to the formation of precipitates such as $\mathrm{CaCO}_{3}$ and $\mathrm{Ca}\left(\mathrm{HCO}_{3}\right) 2$ (Qadir et al. 1996). The effect of humic acid on decreasing the soil $\mathrm{pH}$ could be explained by the effect of protons $(\mathrm{H}+)$. Humic acids contain carboxyl $(-\mathrm{COOH})$ and phenolic hydroxyl $(-\mathrm{OH})$ groups which can release $\mathrm{H}^{+}$to directly neutralize soil alkalinity. Shaban et al. (2018) reported that the application of $\mathrm{K}$ fertilizers minimize adsorption of $\mathrm{Na}$ at the cation-exchange sites on soil particles, so enhancing Na leaching losses. The decrease in the soil $\mathrm{pH}$ may be due to a dual effect of the $\mathrm{K}$-salt ions. According to the order of $\mathrm{K}+$ in the lyotropic series along with the acid radical (humate) effects, and $\mathrm{K}^{+}$exchanges for $\mathrm{Na}^{+}$in the root zone. Sodium replaces the $\mathrm{K}^{+}$in their salts and $\mathrm{K}+$ is released into soil solution and becomes available to plant.

Table 4: Mean values of soil $\mathrm{pH}, \mathrm{EC}\left(\mathrm{dSm}^{-1}\right)$ in soil after carrot harvesting (two seasons).

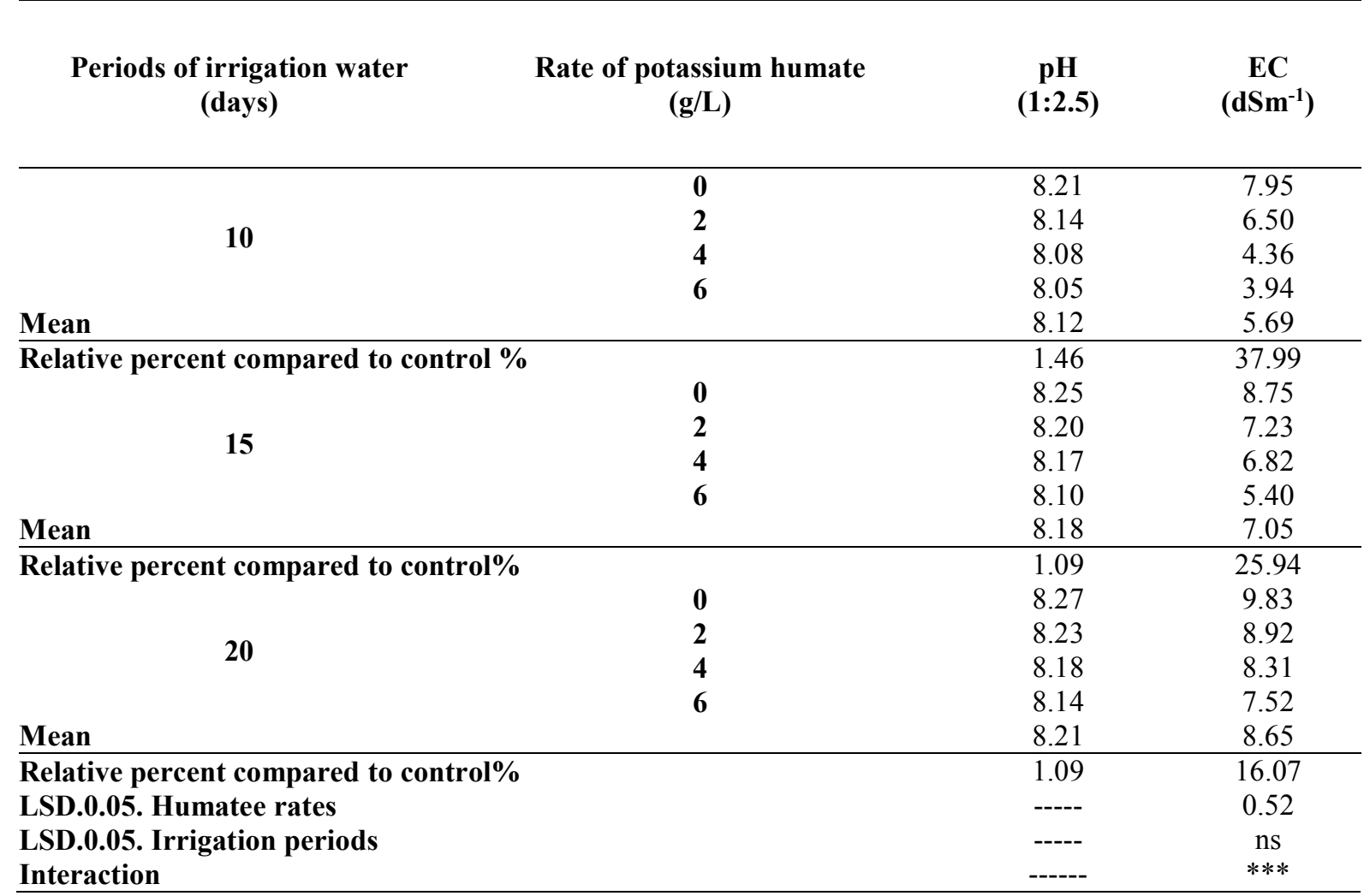

\section{2-Soil salinity}

The EC values of studied soils after carrot harvesting as shown in Table (4) reveal that the soil salinity values tend to decrease by increasing potassium humate rate and decreasing irrigation water period, the 10 days irrigation period showed the lowest mean EC value $\left(5.96 \mathrm{dsm}^{-1}\right)$ compared to other irrigation periods. Application of potassium humate regardless the rate of application led to a significant 
decrease in soil salinity. Also, soil salinity had an insignificant result with different irrigation periods studied.

The interaction between the irrigation periods at different rates of potassium humate was significant. The relative decreases of mean values of soil salinity were $37.99 \% ; 25.94 \%$ and $16.07 \%$ for soil treated with different rates of potassium humate at irrigation water periods of 10,15 and 20 days respectively compared to which without potassium humate treatments. These results are in agreement with Khaled and Fawy (2011) who reported that application of potassium humate has been identified to reduce the soil salinity. Turan et al. (2011) suggested that application of potassium humate to soil led to decreases of soil salinity. This reduction of soil salinity was because of potassium humate can increase aggregate stability and $\mathrm{K}^{+}$replaced them on the surface of colloid adsorption so the proportion of $\mathrm{K}$ increased, Mindari et al. (2014). Kamel et al. (2017) found that the decrease of ECe in first and second seasons was attributable to the leaching that had occurred during both winter periods. The total rainfall was increase during carrot growing season. These results could be explained may be due to the reflection of the activity of microorganisms in reducing salinity and simultaneously improving soil structure; increasing drainable pores, total porosity and aggregate stability, and consequently enhanced leaching process through irrigation fractions.

\section{3-Available macronutrients content in soil.}

Available macronutrients (N, P and K) content in soil are presented in Table (5). The results raveled that the effect of irrigation water periods and different rates of potassium humate on available $\mathrm{N}, \mathrm{P}$ and $\mathrm{K}$ contents in soil after carrot harvesting were increased with increasing potassium humate rates and irrigation water amount. The highest mean values of soil available $\mathrm{N}, \mathrm{P}$ and $\mathrm{K}$ were in soil treated with irrigation water period 10 days combined with potassium humate, while the corresponding mean values for the irrigation water periods 15, 20 days recorded the least.

Table 5: Mean values of available macronutrients and micronutrients in soil after carrot harvesting (two seasons).

\begin{tabular}{|c|c|c|c|c|c|c|c|}
\hline \multirow{2}{*}{$\begin{array}{c}\text { Periods of irrigation } \\
\text { water } \\
\text { (days) }\end{array}$} & \multirow[t]{2}{*}{$\begin{array}{l}\text { Rate of potassium humate } \\
\qquad(\mathrm{g} / \mathrm{L})\end{array}$} & \multicolumn{3}{|c|}{$\begin{array}{c}\text { Available } \\
\text { macronutrients } \\
\left(\mathrm{mgkg}^{-1}\right)\end{array}$} & \multicolumn{3}{|c|}{$\begin{array}{c}\text { Available } \\
\text { micronutrients } \\
\left(\mathrm{mgkg}^{-1}\right)\end{array}$} \\
\hline & & $\mathbf{N}$ & $\mathbf{P}$ & $\mathbf{K}$ & $\mathbf{F e}$ & Mn & $\mathbf{Z n}$ \\
\hline \multirow{4}{*}{10} & $\mathbf{0}$ & 40.62 & 4.89 & 192.00 & 5.88 & 2.82 & 0.69 \\
\hline & 2 & 42.10 & 5.10 & 197.00 & 5.93 & 3.10 & 0.72 \\
\hline & 4 & 44.86 & 5.68 & 201.00 & 6.04 & 3.17 & 0.76 \\
\hline & 6 & 47.52 & 6.10 & 205.00 & 6.12 & 3.19 & 0.83 \\
\hline Mean & & 43.78 & 5.44 & 198.75 & 5.99 & 3.07 & 0.75 \\
\hline \multicolumn{2}{|c|}{ Relative percent compared to control\% } & 10.36 & 15.13 & 4.96 & 2.55 & 11.70 & 11.59 \\
\hline \multirow{4}{*}{15} & 0 & 40.22 & 4.55 & 190.00 & 5.79 & 2.80 & 0.67 \\
\hline & 2 & 41.30 & 4.79 & 194.00 & 5.84 & 2.88 & 0.69 \\
\hline & 4 & 42.96 & 4.93 & 199.00 & 5.97 & 2.94 & 0.72 \\
\hline & 6 & 43.88 & 5.04 & 203.00 & 6.02 & 3.05 & 0.78 \\
\hline Mean & & 42.09 & 4.83 & 196.50 & 5.91 & 2.92 & 0.72 \\
\hline \multicolumn{2}{|c|}{ Relative percent compared to control\% } & 6.19 & 8.13 & 4.21 & 2.59 & 5.71 & 8.96 \\
\hline \multirow{4}{*}{20} & 0 & 39.52 & 4.52 & 189.10 & 5.78 & 2.71 & 0.66 \\
\hline & 2 & 40.12 & 4.66 & 192.00 & 5.80 & 2.79 & 0.68 \\
\hline & 4 & 40.77 & 4.79 & 194.00 & 5.89 & 2.85 & 0.70 \\
\hline & 6 & 41.30 & 4.82 & 197.00 & 5.93 & 2.93 & 0.74 \\
\hline Mean & & 40.43 & 4.70 & 193.03 & 5.85 & 2.82 & 0.70 \\
\hline \multicolumn{2}{|c|}{ Relative percent compared to control\% } & 3.06 & 5.31 & 2.06 & 1.56 & 5.54 & 7.58 \\
\hline \multicolumn{2}{|c|}{ LSD.0.05. Humate rates } & 1.38 & ns & ns & 2.24 & Ns & 0.018 \\
\hline \multicolumn{2}{|c|}{ LSD.0.05. Irrigation periods } & Ns & 0.73 & 1.64 & 1.03 & Ns & $\mathrm{Ns}$ \\
\hline \multicolumn{2}{|c|}{ Interaction } & ** & $* * *$ & $* * *$ & $* * *$ & Ns & $* * *$ \\
\hline
\end{tabular}

The effect of potassium humate rates on available soil $\mathrm{N}$ was significant whereas for soil available $\mathrm{P}$ and $\mathrm{K}$ was insignificant. Respect to effect of irrigation water periods, its effect was insignificant for available soil $\mathrm{N}$, while for the available soil $\mathrm{P}$ and $\mathrm{K}$ was significant. The relative increase of mean 
values of available macronutrients in soil were $10.36,6.19$ and $3.06 \%$ for $\mathrm{N} ; 15.13,8.13$ and $5.31 \%$ for $\mathrm{P}$ and $4.69,4.21$ and $2.06 \%$ for $\mathrm{K}$ as affected with different irrigation water periods 10,15 and 20 days respectively combined with different rates of potassium humate compared to the soil which without potassium humate application.

From the after mentioned results it is obvious that the increases of available $\mathrm{N}, \mathrm{P}$ and $\mathrm{K}$ in soil were related to the decreasing of irrigation periods in the order (10 days $>15$ days $>20$ days). These results are in agreement with Ibrahim et al. (2015) who found that the effect of different irrigation water rates on available $\mathrm{N}\left(\mathrm{mgkg}^{-1}\right)$ content in soil had insignificant increases, while the $\mathrm{P}$ and $\mathrm{K}$ content in soil were significantly affected. On the other hand, the interaction between different rates of potassium humate and irrigation water periods on available N, P and K contents in soil were significant. Yuncal and Urs (2005) found that the drought stress conditions led to decreasing the available N, P and K in soil. Hui et al., (2012) reported that application of potassium humate increases significantly the soil organic matter, available $\mathrm{N}, \mathrm{P}$ and $\mathrm{K}$ in soil. Application of humic acid at a rate of $1,000 \mathrm{mg} \mathrm{kg}^{-1}$ to saline soil gave an increase in seed germination, plant growth, and macro- and micronutrient contents of tomato (Turkmen et al., 2004).

According to Selim et al., (2009) who stated that the application of humic substances by fertigation increased the level of macro- and micronutrients that were retained in soil after potato harvesting.

\section{4-Available micronutrients content.}

The data recorded in Table (5) pronounced that there were increases in soil available micronutrients contents i.e $\mathrm{Fe}, \mathrm{Mn}$ and $\mathrm{Zn}\left(\mathrm{mg} \mathrm{kg}^{-1}\right)$ as a result of different irrigation water periods ( 10, 15 and 20 days) with or without adding potassium humate. The increment in available micronutrients may be returned to the presence of residual organic compounds, which act as chelating and ion exchange compounds and reserve the available micronutrients from leaching out by the irrigation water. The highest values of micronutrients were obtained in the soil treated with potassium humate at rate $6 \mathrm{~g} / \mathrm{L}$ and water period of 10 days continuously. Concerning, the relative increases of mean values of micronutrients availability as affected by different rates of potassium humate compared to control, the corresponding values were $2.55 \%, 2.59 \%$ and $1.56 \%$ for $\mathrm{Fe}$, and $11.70 \%, 5.71 \%$ and $5.54 \%$ for $\mathrm{Mn}$ and $11.59 \%, 8.96 \%$ and $7.58 \%$ for $\mathrm{Zn}$ at $10,15,20$ days of irrigation water periods respectively.

In general, the positive effects of the used different irrigation water periods on available $\mathrm{Mn}$ and Zn could be arranged in the following order: $10>15>20$ days water period combined with potassium humate. While for $\mathrm{Fe}$ the order of availability in soil was $15>10>20$ days water period at different rate of potassium humate. From the aforementioned results, it could concluded that $\mathrm{Fe}, \mathrm{Mn}$ and $\mathrm{Zn}$ tend to increase in the studied soils with increasing different rates of potassium humate and increase of irrigation water quantity. Dasgupta et al. (2015) found that the decrease in Fe, Mn, and Zn availability with soil water stress to increased soil pH in soil. Mousa and Shaban (2017) reported that the increases of Fe, $\mathrm{Mn}$ and $\mathrm{Zn}$ contents in soil were more pronounced at the highest rates of irrigation. Abou Hussien and Shaban (2008) found that the increase of irrigation water period from El-Salam canal gave increment of micronutrients content in saline soil.

\section{5- Carrot productivity.}

Potassium humate application is very important for carrot plants. Date presented in Table (6) show that there were a significant effect of both of potassium humate treatments and different applied water periods on each of weight of fresh roots and the carrot yield. Application of $6 \mathrm{~g} / 1$ of potassium humate at (10days) irrigation period recorded the highest response i.e. plant height $(\mathrm{cm})$, Root length $(\mathrm{cm})$, root diameter $(\mathrm{cm})$, weight of fresh root $(\mathrm{g})$ and weight of fresh root yield (ton/fed) over the two seasons. These results may be due to the role of potassium element in metabolism and many processes needed to promote plant vegetative growth and development of roots.

These results are in agreement with Hossain et al. (2009) indicate that carrot yield and its components (root length, root diameter and root weight) were significantly increased by increasing $\mathrm{K}$ fertilizer, which could be attributed to the stimulatory effect of $K$ on rate of photosynthesis, as well as, transport of the photosynthetic product from the leaves to the storage organ (carrot roots ). In addition, potassium humate application led to improving plant growth parameters, yield and quality of sweet pepper plant (El - Bassiony et al., 2010). Ali (2017) reported that the values of quality parameters for 
carrot roots (length $(\mathrm{L}) \mathrm{cm}$, diameter (D) $\mathrm{cm}$ and root yield/fed decreased with increasing deficit irrigation during growth stages. These results may be attributed to that the initial and development growth stages of carrot roots were very sensitive for deficit irrigation. Potassium $(\mathrm{K})$ is a crucial element for optimal potato production, which is unlike the speci fi c nutrient requirements of most other vegetable crops. Potassium is important to potato, as it strengthens stems and thus helps to prevent lodging, increases tuber yield, size and quality, increases specific gravity and starch content, and improves fry color and storage quality (Ibrahim et al., 1987). It also allows adapt the crops to the environmental stress viz. salinity stress and water stress (Kanai et al. 2011). The application of HA likely decreased $\mathrm{K}^{+}$leaching due to the influence of functional groups commonly present in HA, including carboxyl, phenol and hydroxyl, which contributed in $\mathrm{K}^{+}$binding by HA (Wang and Huang 2001 ). Furthermore, humic acid could have had a stimulating effect on plant physiological properties, thereby increasing K uptake. According to (Samson and Visser 1989), humic acid can induce an increase in the permeability of biomembranes for electrolytes, resulting in increased uptake of $\mathrm{K}$.

Table 6: Effect of different irrigation water periods with or without potassium humate rates on carrot productivity (two seasons).

\begin{tabular}{|c|c|c|c|c|c|c|}
\hline $\begin{array}{c}\text { Periods of } \\
\text { irrigation } \\
\text { water } \\
\text { (days) }\end{array}$ & $\begin{array}{c}\text { Rate of potassium } \\
\text { humate } \\
\text { ml/L }\end{array}$ & $\begin{array}{l}\text { Plant } \\
\text { height } \\
\text { (cm) }\end{array}$ & $\begin{array}{l}\text { Root } \\
\text { length } \\
(\mathrm{cm})\end{array}$ & $\begin{array}{l}\text { Root } \\
\text { diameter } \\
(\mathrm{cm})\end{array}$ & $\begin{array}{c}\text { Weight of } \\
\text { Fresh } \\
\text { roots (g) }\end{array}$ & $\begin{array}{l}\text { Weight of } \\
\text { fresh root } \\
\text { (ton/fed) }\end{array}$ \\
\hline \multirow{4}{*}{10} & $\mathbf{0}$ & 53.66 & 14.60 & 2.88 & 41.78 & 11.44 \\
\hline & 2 & 55.98 & 16.58 & 2.97 & 49.55 & 14.90 \\
\hline & 4 & 58.88 & 18.22 & 3.12 & 55.93 & 16.17 \\
\hline & 6 & 62.10 & 20.57 & 3.19 & 58.90 & 17.00 \\
\hline Mean & & 57.66 & 17.49 & 3.04 & 51.54 & 14.88 \\
\hline \multirow{4}{*}{15} & 0 & 50.29 & 13.86 & 2.35 & 40.45 & 10.20 \\
\hline & 2 & 54.88 & 14.55 & 2.56 & 48.92 & 13.65 \\
\hline & 4 & 55.60 & 16.00 & 2.75 & 53.72 & 14.00 \\
\hline & 6 & 57.10 & 17.95 & 2.84 & 56.88 & 14.78 \\
\hline Mean & & 54.47 & 15.59 & 2.63 & 49.99 & 13.16 \\
\hline \multirow{4}{*}{20} & $\mathbf{0}$ & 48.94 & 12.66 & 2.18 & 39.60 & 8.99 \\
\hline & 2 & 53.90 & 13.74 & 2.25 & 42.56 & 10.75 \\
\hline & 4 & 54.00 & 13.80 & 2.58 & 44.20 & 11.74 \\
\hline & 6 & 55.38 & 14.00 & 2.64 & 44.89 & 12.35 \\
\hline Mean & & 53.06 & 13.55 & 2.41 & 42.81 & 10.96 \\
\hline \multicolumn{2}{|c|}{$\begin{array}{l}\text { llean } \\
\text { LSD. } 0.05 \text {. Humate rates }\end{array}$} & 2.14 & 1.83 & 0.20 & 2.21 & 2.03 \\
\hline \multicolumn{2}{|c|}{ LSD.0.05. Irrigation periods } & 2.36 & ns & 0.23 & 2.80 & 0.99 \\
\hline Interaction & & $*$ & $*$ & $*$ & $* *$ & $* *$ \\
\hline
\end{tabular}

\section{6-Macronutrients concentrations in leaves and roots.}

The Data presented in Table (7) show that the potassium humate application has a significant increase on $\mathrm{N}, \mathrm{P}$ and $\mathrm{K}$ concentrations in leaves and roots of carrot plants and this increase was pronounced with increasing the rate of application. Respect to the different periods of irrigation also recorded significant increases on $\mathrm{N}$ and $\mathrm{K}$ concentration in root carrot plants with decreasing irrigation of water periods.Also The interaction between potassium humate and irrigation water periods on $\mathrm{N}, \mathrm{P}$ and $\mathrm{K}$ concentrations in leaves and root carrot plants had significant increases effect.

The data previously show that the sequence of N, P and K concentrations in leaves and roots as affected by irrigation water periods and different rates of potassium humate could be arranged according to their concentrations in the following order:

$10>15>20$ days for $\mathrm{N}$ and $\mathrm{K}$ in leaves and roots carrot plants

$15>10>20$ days for $\mathrm{P}$ in leaves and roots carrot plants compared to control. These results are in agreement by Ounia et al. (2014) who found that the potassium humate promote the conversion of a number of mineral elements into available forms to plants. Foliar application of potassium humate is increasingly used in agricultural practice, the mechanism of possible growth promoting effect, usually attributed to hormone-like impact, activation of photosynthesis, accelerate cell division, increase the permeability of plant cell membranes and improved nutrient uptake, reduce the uptake of toxic elements 
and improve the plant response to salinity (Verlinden et al. 2009). El-Tohamy et al. (2011) indicated that the increasing of potassium rates increased $\mathrm{N}, \mathrm{P}$ and $\mathrm{K}$ concentrations in leaves and roots of carrot plants. These results may be due to the role of potassium in plant metabolism and many important regulatory processes in the plant. Jalil et al. (2013) found that the potassium humate is an active compound of natural origin which increases uptakes $\mathrm{N}, \mathrm{P}, \mathrm{K}$ and micronutrients.

Table 7: Effect of drought and K- fertilizer rate on macronutrients concentration in leaves and root carrot plants. (two seasons)

\begin{tabular}{|c|c|c|c|c|c|c|c|}
\hline \multirow{2}{*}{$\begin{array}{c}\text { Periods of } \\
\text { irrigation } \\
\text { water } \\
\text { (days) }\end{array}$} & \multirow{2}{*}{$\begin{array}{c}\text { Rate of } \\
\text { potassium } \\
\text { humate }(g / L)\end{array}$} & \multicolumn{2}{|c|}{$\begin{array}{c}\mathrm{N} \\
(\%)\end{array}$} & \multicolumn{2}{|c|}{$\begin{array}{c}\mathbf{P} \\
(\mathbf{\%})\end{array}$} & \multicolumn{2}{|c|}{$\begin{array}{c}\mathbf{K} \\
(\%)\end{array}$} \\
\hline & & Leaves & Roots & Leaves & Roots & Leaves & Roots \\
\hline \multirow{4}{*}{10} & 0 & 2.23 & 1.18 & 0.26 & 0.35 & 1.95 & 2.44 \\
\hline & 2 & 2.29 & 1.23 & 0.31 & 0.41 & 2.34 & 2.79 \\
\hline & 4 & 2.35 & 1.25 & 0.34 & 0.47 & 2.75 & 3.07 \\
\hline & 6 & 2.39 & 1.30 & 0.36 & 0.51 & 2.83 & 3.15 \\
\hline Mean & & 2.32 & 1.24 & 0.32 & 0.44 & 2.47 & 2.86 \\
\hline \multirow{4}{*}{15} & 0 & 2.26 & 1.20 & 0.27 & 0.36 & 2.00 & 2.55 \\
\hline & 2 & 2.33 & 1.25 & 0.33 & 0.42 & 2.55 & 2.88 \\
\hline & 4 & 2.46 & 1.27 & 0.38 & 0.48 & 2.83 & 3.12 \\
\hline & 6 & 2.50 & 1.32 & 0.42 & 0.53 & 2.93 & 3.24 \\
\hline Mean & & 2.39 & 1.26 & 0.35 & 0.45 & 2.58 & 2.95 \\
\hline \multirow{4}{*}{20} & 0 & 2.19 & 1.04 & 0.25 & 0.34 & 1.75 & 2.33 \\
\hline & 2 & 2.23 & 1.08 & 0.28 & 0.40 & 1.85 & 2.48 \\
\hline & 4 & 2.26 & 1.13 & 0.29 & 0.46 & 1.98 & 2.56 \\
\hline & 6 & 2.29 & 1.16 & 0.31 & 0.47 & 2.07 & 2.60 \\
\hline Mean & & 2.24 & 1.10 & 0.28 & 0.42 & 1.91 & 2.49 \\
\hline \multirow{3}{*}{\multicolumn{2}{|c|}{$\begin{array}{l}\text { LSD.0.05. Humate rates } \\
\text { LSD.0.05. Irrigation periods } \\
\text { Interaction }\end{array}$}} & 0.06 & 0.04 & 0.014 & 0.030 & 0.032 & 0.019 \\
\hline & & ns & 0.22 & Ns & ns & Ns & 0.021 \\
\hline & & $* * *$ & $* * *$ & $* * *$ & $* * *$ & $* * *$ & $* * *$ \\
\hline
\end{tabular}

\section{Micronutrients concentrations in leaves and roots .}

Effect of irrigation periods and different rates of potassium humate on the concentrations of some micronutrients ( $\mathrm{Fe}, \mathrm{Mn}$ and $\mathrm{Zn} \mathrm{mg} / \mathrm{kg}$ ) in leaves and root of carrot plants are presented in Table (8). The data obtained show that applying the different rates of potassium humate and irrigation water periods caused markedly increases in the concentrations of Fe, $\mathrm{Mn}$ and $\mathrm{Zn}$ in leaves and roots carrot plants, with a more pronouncing increase with increasing the rate of potassium humate and the irrigation water quantity. The $\mathrm{Fe}$ and $\mathrm{Zn}$ concentrations in leaves and roots were insignificant, while the Mn had significant increase as affected with different rates of potassium humate. Also the effect of irrigation water periods on $\mathrm{Fe}, \mathrm{Mn}$ and $\mathrm{Zn}$ concentrations in leaves and roots were insignificant.in addition, the interaction between potassium humate rates and irrigation water periods were significant in increasing Fe and Mn contents in leaves and roots of carrot plants, but insignificant for Zn content. Ahmed et al. (2017) found that potassium humate contains many elements necessary to the plant life development and the mechanism of possible growth promoting effect, usually attributed to hormone and improved nutrient uptake. Hussein and Hassan (2011) reported that the foliar application in $0.1 \%$ humic acid treatment increased the Fe, Zn, and Mn amounts in plants. Deepesh et al. (2018) observed that there was a decrease of nutrients concentrations in root plants with drought. Humic acids are an important soil component that can improve nutrient availability and impact on other important chemical, biological, and physical properties of soils. The effects of foliar and soil applications of humic substances on the plant growth and some nutrient elements uptake of Corn (Hagein, Fardy 10) grown at various salt concentrations were examined Hussein and Hassan (2011).

Finally, it is concluded that the concentrations of micronutrients in carrot plants, generally, reflect their available contents in soil due to the effect of irrigation water periods under different rates of potassium humate treatments. 
Table 8: Effect of drought and K- fertilizer rate on micronutrients concentration in leaves and root carrot plants (two seasons).

\begin{tabular}{|c|c|c|c|c|c|c|c|}
\hline \multirow{2}{*}{$\begin{array}{l}\text { Periods of } \\
\text { irrigation } \\
\text { water } \\
\text { (days) }\end{array}$} & \multirow{2}{*}{$\begin{array}{l}\text { Rate of potassium } \\
\text { humate }(\mathrm{ml} / \mathrm{L})\end{array}$} & \multicolumn{2}{|c|}{$\begin{array}{c}\mathrm{Fe} \\
(\mathrm{mg} / \mathrm{kg})\end{array}$} & \multicolumn{2}{|c|}{$\begin{array}{c}\mathrm{Mn} \\
(\mathrm{mg} / \mathrm{kg})\end{array}$} & \multicolumn{2}{|c|}{$\begin{array}{c}\mathrm{Zn} \\
(\mathrm{mg} / \mathrm{kg})\end{array}$} \\
\hline & & Leaves & Roots & Leaves & Roots & Leaves & Roots \\
\hline \multirow{4}{*}{10} & $\mathbf{0}$ & 46.90 & 65.88 & 28.94 & 31.87 & 12.98 & 20.67 \\
\hline & 2 & 47.75 & 71.45 & 30.66 & 32.33 & 13.23 & 21.45 \\
\hline & 4 & 49.81 & 74.89 & 31.84 & 33.00 & 13.88 & 22.90 \\
\hline & 6 & 53.10 & 79.60 & 32.80 & 33.85 & 14.25 & 23.11 \\
\hline Mean & & 49.39 & 72.96 & 31.06 & 32.76 & 13.59 & 22.03 \\
\hline \multirow{4}{*}{15} & $\mathbf{0}$ & 47.39 & 68.97 & 29.55 & 32.80 & 13.00 & 22.30 \\
\hline & 2 & 48.96 & 74.30 & 33.29 & 33.61 & 13.95 & 22.80 \\
\hline & 4 & 50.43 & 79.47 & 33.85 & 34.34 & 14.51 & 23.18 \\
\hline & 6 & 54.89 & 82.00 & 34.78 & 35.00 & 15.12 & 23.85 \\
\hline Mean & & 50.42 & 76.19 & 32.87 & 33.94 & 14.15 & 23.03 \\
\hline \multirow{4}{*}{20} & $\mathbf{0}$ & 45.86 & 63.91 & 24.70 & 30.77 & 12.97 & 19.40 \\
\hline & 2 & 47.30 & 67.44 & 27.22 & 32.10 & 13.89 & 20.33 \\
\hline & 4 & 47.88 & 69.50 & 27.95 & 32.70 & 13.00 & 20.75 \\
\hline & 6 & 48.00 & 72.33 & 29.20 & 33.52 & 13.15 & 21.29 \\
\hline Mean & & 47.26 & 68.30 & 27.27 & 32.27 & 13.25 & 20.44 \\
\hline \multicolumn{2}{|c|}{ LSD.0.05. Humate rates } & Ns & $\mathrm{ns}$ & 1.79 & Ns & $\mathrm{ns}$ & Ns \\
\hline \multirow{2}{*}{\multicolumn{2}{|c|}{$\begin{array}{l}\text { LSD.0.05. Irrigation periods } \\
\text { Interaction }\end{array}$}} & Ns & ns & ns & Ns & ns & Ns \\
\hline & & $* * *$ & ** & ** & $* * *$ & ns & Ns \\
\hline
\end{tabular}

\section{Conclusion}

From the after mentioned results there was an interaction between the doses of potassium humate at different irrigation water periods on improving soil alkalinity and salinity and plant growth. The best treatment combination was $6 \mathrm{~g} / \mathrm{L}$ with irrigation water periods of 10 days. Our results showed that irrigating of carrot with 10 days combined with or without potassium humate could increased carrot yield. However, reschedule irrigation and applying water after 20 days alone led to reduced yield. These findings implied that avoiding sensitive growth stages to water stress in carrot could help in saving an ample amount of irrigation water. This means that the deficit irrigation technology during different growth stages can be recommended to apply on the carrot plants to find out sensitive and tolerant stages to apply it and therefore, save more irrigation water with increase of root carrot yield.

\section{References}

Abdel Naby , H. M. E., K. K. Daa, E. E. El-Gamily and S.M. Abd El-Hameed, 2013. Effect of organic, bio and mineral fertilization on yield and quality of r4e 4 crrot plants. J. Plant Production, Mansoura Univ., 4 (2): 336- 349.

Ahmed, A.M.M., Ibraheim, S. Kh. A. and M. K. Abdel-Fattah, 2017. Effect of potassium humate, nitrogen biofertilizer and molybdenum on growth and productivity of garlic (Allium sativum L.). Current Sci. Inter., 6 (1): 75- 85.

Chapman, H. D. and P. E. Pratt, 1978. Methods of analysis for soils, plants, and waters. Univ. of Calif., Div. Agric. Sci., Priced Pub., 4034.

Dasgupta, P., B. Das and S. Sen, 2015. Soil water potential and recoverable water stress in drought tolerant and susceptible rice varieties. Agricultural Water Management, 152, 110-118.

Deepesh, R. B., A.H. Scott, M.J. Dileepa, M. Saamita and K.B. Jennifer, 2018. Effects of drought on nutrient uptake and the levels of nutrient uptake proteins in Roots of drought sensitive and tolerant grasses. Pants Basel., 7 (2): 28- 35.

El-Bassiony, A.M, Z. F. Fawzy, E.H. Abd El-Samad, and G. S. Raid, 2010. Growth, yield and fruit quality of sweet pepper plants (Capsicum annuum L.) as affected by potassium fertilization. Journal of American Science, 6(12):722-729. 
El-Tohamy, W. A., H.M. El-Bagy, M.A. Badr, S.D. Abou- Hassein and Y. I. Helmy, 2011. The influence of foliar application of potassium on yield and quality of carrot (Daucus carota L.) Plants Grown under Sandy Soil Conditions. Austr. J. of Basic and Appl. Sci. 5 (3): 171- 174.

FAO, 2003. Food and Agriculture Organization of the United Nation. Salt affected soils, contract No. PR 26897. ISCW Project Gw 561003120.

Feng Que, Xi-Lin Hou, Guang-Long Wang, Zhi-Sheng Xu, Guo-Fei Tan, Tong Li, Ya-Hui Wang, Ahmed Khadr, and Ai-Sheng Xiong, 2019. Advances in research on the carrot, an important root vegetable in the apiaceae family. Hortic. J. Res., $6: 69-75$.

Geerts, S. and D. Raes, 2009. Deficit Irrigation as an On-Farm Strategy to Maximize Crop Water Productivity in, Dry Areas. Agricultural Water Management, 96, 1275-1284.

Hossain, A. K. M. M., M. R. Islam, M. S. Bari, M. H. A. Amin, and M. A. Kabir, 2009. Effects of mulching and levels of potassium on growth and yield of carrot. Bangladesh Research Publications Journal, 3 (2): 963-970.

Hui, J. L., H.L. Jing, Y.U. Jian, and T.X. Sheng, 2012. Effect of soil amendment on soil physical and chemical properties in Oat field. J. Advanced Material Res., (610- 613) : 2937 - 2943.

Hussein, Kh. and A. F. Hassan, 2011. Effect of different levels of humic acids on the nutrient content, plant growth and soil properties under conditions of salinity. J. Soil and Water Res., 6 (1): 21 - 29.

Ibrahim, H. I. M., A. M. S. Sallam, and Shaban, Kh. A., 2015. Impact of irrigation rates and potassium silicate on seed production and quality of Fahl Egyptian Clover and soil properties under saline conditions. American -Eurasian J. Agric. and Enviro. Sci. 15 (7): 1245- 1255.

Ibrahim, S.A., A.I. El-Zawily and E.A. Zayed, 1987 Effect of NPK level and ratio on growth, yield and chemical composition of potato plants grown in sandy loam soil. Egypt J Soil Sci 27(2):131-144.

Jackson, M.L., 1973. Soil Chemical Analysis, Prentice-Hall, Inc., Englewood Califfs, New Jersy

Jalil, A., V. Saeid, P. Farzad, R. Mohammad and K. Ali, 2013. Effect of potassium humatee on yield and yield components of different potato varieties as a second crop after barley harvest in ardabil region, Iran. Annals of Biol. Res., 4 (2): 85-89.

Johan, T.V.T., 2008. Effect of potassium humatee on soil properties and growth of wheat. M.Sc. Thesis, Fac. of Agric., Natural and Agric Sci. Univ. the Free State. Bloemfonten.

Kamal, N., F. El-Mokh, M.M. Mohamed and B.M. Netij, 2017. Studying the effects of deficit irrigation as on farm strategy on carrot yield in arid environment. Inter. J. of Crop. Sci. and Tech. 3 (2): $42-$ 50 .

Kanai, S, R.E. Moghaieb, H.A. El-Shemy, R. Panigrahi, P.K. Mohapatra, J. Ito, N.T. Nguyen, H. Saneoka and K. Fujita, 2011. Potassium de fi ciency affects water status and photosynthetic rate of the vegetative sink in green house tomato prior to its effects on source activity. Plant Sci 180:368-374.

Khaled, H. and H.A. Fawy, 2011. Effect of different levels of humic acids on the nutrient content, plant growth, and soil properties under conditions of salinity. Soil and Water Research 6 (1): 21-29.

Khordhidi, M. B., A.H. Hosseini, D.P. Hassan, M. Yarny and J. Ajally, 2009. The First National Conference on Environmental Stresses in Agricultural Science, Birjand University, February 2009, Iran.

Li, M., L.L. Jiang, Z.J. Sun, J.Z. Wang, Y.C. Rui, L. Zhong, Y.F. Wang and P. Kardol, 2012. Effects of flue gas desulfurization gypsum by-products on microbial biomass and community structure in alkaline-saline soils.

Marzouk, Neama M., R.E. Abdelraouf, S.R. Salman and M.M.H. Abd El Baky, 2016. Effect of Water Stress on Yield and Quality Traits of Different Snap Bean Varieties Grown in an Arid Environment. Middle East J. Agric. Res., 5(4): 629-635.

Mehdi, S.M., M. Sarfaz and M. Hafeez, 2007. Response of rice advance line P.B- 95 to potassium application in saline-sodic soil. Pak. J. Biol. Sci., 10: 93-99.

Mindari, W., A. Aini, Z. Kusuma and S. Yekhfani, 2014. Effects of humic acid based buffer cation on chemical chrematistics of saline soils and maize growth. J. of Degraded and Mining Lands Management, 2 (1): 259- 268.

Qadir, M., R.H. Qureshi and N. Ahmad, 1996. Reclamation of a saline-sodic soil by gypsum and Leptochloa fusca. Geoderma 74:207-217. 
Ounia, Y., T. Ghnaya, F. Montemurro, Ch. Abdelly, A. Lakhdar, 2014. The role of humic substances in mitigating the harmful effects of soil salinity and improve plant productivity. Int. J. Plant Prod., 8(3):353-374.

Page, A.L., R.H. Miller and D.R. Keeny, 1982. Methods of Soil Analysis Part2 Chemical and Biological Properties. Amer. Soc. Agron. Inc. Mascson, Wisconsin USA.

Samson, G. and S.A. Visser, 1989. Surface-active effects of humic acids on potato cell membrane properties. Soil Biol Biochem., 21:343-347.

Selim, E.M., A.A. Mosa and A.M. El-Ghamry, 2009. Evaluation of humic substances fertigation through surface and subsurface drip irrigation systems on potato grown under Egyptian sandy soil conditions. Agric Water Manag, 96:1218-1222

Shaban, KH. A., 2005. Effect of different irrigation water resources on properties and productivity of salt affected soils. Ph.D. Thesis, Fac . Agric .Monufiya Univ. Egypt.

Sommers, L.E. and D.W. Nelson, 1972. Determination of total phosphorus in soil. A rapid perchloric acid digestion procedure .Soil Sci. Soc. Amer. Proc., 36: 902-904.

Turan, M.A., B.B. Asik, A.V. Katkat, and H. Celik, 2011.The effects of soil-applied humic substances to the dry weight and mineral nutrient uptake of maize plants under soil-salinity conditions. Notulae Botanicae Horti Agrobotanici Cluj-Napoca 39(1):171-177.

Türkmen O, Dursun A, Turan M, Erdinc C (2004) Calcium and humic acid affect seed germination, growth and nutrient content of tomato (Lycopersicon esculentum L.) seedlings under saline soil conditions. Acta Horticul Scandinavica B., 54:168-174.

Verlinden, G., B. Pycke, J. Mertens, F. Debersaques, K. Verheyen, G. Baert, J. Bries and G. Haesaert, 2009. Application of Humic substances results in consistent increases in crop yield and nutrient uptake. Journal of Plant Nutrition, 32: 1407-1426.

Wang, F.L. and P.M. Huang, 2001. Effects of organic matter on the rate of potassium adsorption by soils.Can J Soil Sci 81:325-330.

Webber, H., C. Madramootoo, M. Bourgault, M. Horst, G. Stulina, and D. Smith, 2007. Plant-Soil Water Dynamics of Alternative Furrow and Regulated Deficit Irrigation for Two Legume Crops in the Fergana Valley, Uzbekistan.

Yuncal, H. and S. Urs, 2005. Drought and salinity: Acomparison their effects on mineral nutrition of plants. J. plant Nutr. Soil. Sci. $158: 541-549$. 